\title{
The Factors that Affect the Process of Integration and Application of the ICT Program in the Arab Education System in Israel
}

\author{
Habib Allah SOLEMAN ${ }^{1}$ \\ Doina DANAIATA ${ }^{2}$
}

\begin{abstract}
The article explores the connection between the level of the teacher's pedagogic technical knowledge and assimilating an ICT program in school in the Arab sector in Israel, and the impact of the teachers' attitudes on assimilating ICT programs. The research findings indicate that when the teacher thinks that the change is correct, and that it is worthwhile for the system to assimilate it better, one can understand that the teacher's readiness for change is most important. One can thus learn that the teacher's trust in the goals of the change is crucial in order for it to be effective. Although the change is in the ICT field, the research findings hone the need to emphasize the pedagogic aspect and the extent of its impact on the success of assimilating and applying the ICT.
\end{abstract}

Keywords: ICT (Integrating Computer Technologies), ICT program, education system, Arab education system, integration, application.

JEL classification: I20, I25, I29

DOI: $10.24818 / \mathrm{RMCI} .2018 .2 .145$

\section{Introduction}

Integrating computer technologies (ICT) in the education system as Mioduser, Nachmias. Tobin \&Forkosh (2006) states is likely to have extensive implications on a variety of domains, such as school life, the organization of time and space, the student's role, the teacher's role and the curriculum etc..Much research on the subject presentdifficulty in assimilating processes of change in

\footnotetext{
${ }^{1}$ Habib Allah Soleman, West University of Timisoara, Romania, E-mail: swakhaled@gmail.com, Telephone: +972552272488

${ }^{2}$ Doina Danaiata, West University of Timisoara, Romania, E-mail: doina.danaiata@euvt.ro, Telephone : +40724687407
} 
teaching modes and their implementation in schools in general, and in Arab schools that are considered particularly traditional.

Abu Asba (2007) states that despite the progress in the process of integrating computers in education, there is still a disparity between the promise embodied in the information and the ICT revolution and the reality in practice in schools in the Arab sector that suffers from discrimination in budgets for decades. According to Cuban (2001) in recent years, many teachers and students have confirmed that there has indeed been an increase in the use of computers within the classrooms due to increased access to computers, to teacher training, and computer-encouraging policies, but mainly through basic operations such as using a word processor for writing, developing presentations, seeking information on the network, and using electronic mail.

Palak\&Walls (2010) and Hills (2009) has stated that it is important to note that the extent of ICT in the education system in more advanced methods - solving problems using computerized methods, the use of computerized laboratories, managing a classroom internet site, learning together and so on, was lower than expected.

While de Freitas\&Veletsianos (2010) and Selwyn (2010) has sown that many factors influence ICT in the education system, such as attitudes, perceptions, abilities, and teachers' beliefs, towards the digital environments and towards their role in teaching in these environments, and afford key factors that have an impact on the practice of ICT during classroom teaching to assimilate processes of change in teaching methods in schools.

The reasons for difficulties on assimilating ICT in the education system can be divided into two general categories, organizational and administrative, and factors associated with the teaching staff.

An example of an organizational aspect is the structural and operational preparedness of the school to instil change. According to Venezky\&Davis (2002) The prevailing assumption is that there can be no significant change in the education process without structural changes, such as, distribution of classes, flexibility in the content of study units, adjustment of physical learning infrastructures and peripheral equipment, with reference to quality and availability.

The school principal is a key factor influencing changes. Promoted programs encouraged by the principal are more likely to succeed so that the principal provides the vision, directs the teachers towards common goals and drives the necessary resources to promote change.

Marsh (2001) states that many studies have indicated that projects and programs that are encouraged by the manager who have received their support have had very high chances of success due to his involvement, which has been perceived as increasing the seriousness of the project, providing psychological support and mobilizing the necessary resources.

AL-Harbi (2014) and Ghamrawi (2013) found that the principal plays a central role in ICT implementation. For example, if the principal does not provide adequate support and encouragement to teachers, it is not possible to create a good

146 Review of International Comparative Management

Volume 19, Issue 2, May 2018 
working environment to motivate teachers to experiment with information and communication technologies in their classrooms. In addition, Levin and Dudney (2005) confirm that if the principals 'and teachers' beliefs are not constructive in relation to the implementation of ICT, it is reasonable to assume that ICT will not be accepted at all or will be implemented only partially in schools.

Fullan (2006) indicate that entities that interact with the school, such as the local authority and the Ministry of Education, influence the integration of technology there. It can be seen that the multiplicity of entities involved in the processes of change creates great complexity, and frequently the result is requirements that do not correspond to actual reality, simplistic solutions and inconsistency in performance.

Rogers (2003) argues that the process of adopting innovation is multistage: a slow pace at the beginning of the process, then dramatic acceleration, peaking, and then the slowing again. Since the use of basic applications prior to advanced applications, it is not yet possible to obtain the desired educational changes (Ertmer 2005).

Bingimlas (2009) stressed several obstacles, in his study, that may limit the integration of ICT in educational institutions. For example, an increasing number of students in the classroom, inadequate information and communication technology equipment, along with inadequate technical support and maintenance, include lack of incentives for teachers to employ ICT in their classrooms.

\section{Research questions}

The following three questions were examined:

- Is there a connection between the teacher's pedagogic knowledge level and the implementation of the ICT program?

- Is there a connection between each of the components of technological pedagogic knowledge for implementing the ICT program?

- What is the degree of influence of the teacher's attitudes regarding the change in the assimilation of the ICT program?

\section{Methodology}

\section{The research population}

The study population consists of 147 teachers from six elementary schools who participated in the ICT program in the 2007 academic year. All teachers have a "computer for every teacher". The population of the six primary schools is of a low-moderate socioeconomic status, and it is possible that not all students have a computer at home. In the school there are very active computer labs that enable students to experiment with online assignments with the class educators. 


\section{Research tools}

The study used a self-report questionnaire based on Archambult\& Crippen (2009), which included the teachers' demographic data. The questionnaire included several parts:

\section{A. Knowledge of pedagogic content}

Shulman (1986) and Mishra\&Koehler (2008) both state that a conceptual framework for good teaching that included "good pedagogic knowledge" that assumes that at the heart of a good teaching lie three components: content, pedagogy and technology, and the essence of assimilation is related to the relationship and interaction between the three knowledge bases.

\section{B. A questionnaire to examine teachers' attitudes toward change}

A questionnaire according to AvidovUngar\&Friedman (2011) that examined the relationship between "pedagogical knowledge and technological content"and the attitudes of teachers toward change, and the connection between teachers' perception of the school as a learning organization, and their attitudes toward change.

\section{ICT Implementation questionnaire}

A questionnaire based on questions from Peled and Magen Nagar (2012), which investigated differences in skill level, ICT and attitudes toward ICT among teachers in schools demonstrating ICT for regular schools.

\section{Method of data analysis}

In this framework, the analyses were performed using SPSS 19.Data coding and statistical processing was done using descriptive statistics, so that the background data examined the prevalence distribution, averages, standard deviations, standard and distribution ranges, including Pearson coefficients aimed at finding connections between the various research variables.

\section{Findings}

A. Implementation of the ICT program

Teachers report a medium-high level of ICT implementation in their school (3.73 on the scale of 1-5). In Table 1 below. Averages, Standard deviation, Minimum Score Maximum Score, application of ICT.

148 Review of International Comparative Management Volume 19, Issue 2, May 2018 
Table 1: Averages, Standard deviations, minimum and maximum values in the ICT implementation questionnaire

\begin{tabular}{|c|c|c|c|c|c|}
\hline Variable & $\mathrm{N}$ & Average & SD & Min. Score & Max Score \\
\hline ICT impl & 147 & 3.73 & 0.69 & 2.05 & 5.00 \\
\hline
\end{tabular}

\section{B. The teachers' attitudes towards change}

The general attitude of teachers towards the change taking place in the school with the entry of ICT is perceived as positive (3.99 on a scale of 1-5 scale). The highest rating in the questionnaire was afforded to the behavioural component (4.41) and the rating and the lowest rating (3.85) was afforded to the emotional component.

\section{The teachers' level of technological pedagogical knowledge}

There is a high level of contextual pedagogical knowledge among teachers (4.18 on the 1-5 scale), (4.07 on the 1-5 scale), and pedagogical knowledge (4.19 on scale 1-5). A low level was reported in the technological knowledge category (2.71 on a scale of 1-5) and a medium level of knowledge was reported in categories of pedagogical technological knowledge (3.58 on a scale of 1-5) and technological pedagogical content knowledge (3.53 on a scale of 1-5).

\section{The relationship between technological pedagogical knowledge (TPACK) and the implementation of ICT}

All the components of the knowledge were found to have a significant positive correlation with the implementation of the ICT program. That is, the higher the level of technological pedagogical knowledge, the greater the assimilation of the ICT program in the school.

The most prominent categories are technological pedagogical content knowledge (0.61), technological pedagogical knowledge (0.49) and technological knowledge as areas of knowledge (0.52) (see Table 2 below.)

Table 2: Pearson's correlations between technological pedagogical knowledge and the implementation of ICT in school

\begin{tabular}{|l|c|}
\hline \multicolumn{1}{|c|}{ TPACK knowledge } & Implementing ICT program \\
\hline Pedagogical knowledge & $0.27 * *$ \\
\hline Technological knowledge & $0.19 *$ \\
\hline
\end{tabular}

Review of International Comparative Management

Volume 19, Issue 2, May 2018 


\begin{tabular}{|l|c|}
\hline \multicolumn{1}{|c|}{ TPACK knowledge } & Implementing ICT program \\
\hline Knowledge in the field of knowledge & $0.26 * *$ \\
\hline Technological knowledge in the field of knowledge & $0.52 * *$ \\
\hline Pedagogical knowledge in the field of knowledge & $0.42 * *$ \\
\hline Technological pedagogic knowledge & $0.49 * *$ \\
\hline Knowledge of technological pedagogic content & $0.61 * *$ \\
\hline
\end{tabular}

\section{E. The relationship between attitudes toward change and the implementation of ICT in the school}

Among the general attitude of the teachers in the ratio $(r=0.42, p<0.01)$ there was a positive and significant relationship with a moderate intensity of change and the implementation of the ICT program. Thus, the greater the extent to which the respondents are satisfied with the change taking place in the school with the introduction of the ICT program, the greater the degree of assimilation of the ICT program in their school.

An examination of the relationship between the ICT application variable and the three other factors indicates that positive relationships exist $(\mathrm{R}=0.48$, $\mathrm{p}<0.01)$ and the cognitive domains $(\mathrm{r}=0.46, \mathrm{p}=0.01)$ are shown in Table 3.

Table 3: Pearson correlations between attitudes toward change in ICT implementation

\begin{tabular}{|c|c|}
\hline Attitudes towards change & Implementing ICT programs \\
\hline General positions & $0.42 *$ \\
\hline Emotional field & $0.48^{*}$ \\
\hline Behavioural domain & 0.08 \\
\hline Cognitive field & $0.46^{*}$ \\
\hline
\end{tabular}

\section{Summary and discussion}

The goal of the study was to examine what is required of the teacher's knowledge in order to assimilate ICT and whether without the appropriate level of knowledge, but with the willingness to introduce change in teaching, the teacher will be able to implement ICT effectively.

The results of this study, similar to that of AvidovUngar and Arazi (2014), which encompassed schools from the Jewish sector, found that the higher the level of technological pedagogic knowledge, the higher the level of computer assimilation among teachers. It was also found that the level of pedagogic knowledge, contextual knowledge, and pedagogical knowledge of teachers is high. 
On the other hand, it was found that the level of technological pedagogical content knowledge, pedagogical technological knowledge and technological knowledge among teachers is low. It can be seen that the teachers' pedagogical knowledge is very important for the assimilation of ICT.

The research findings also hone the essential differences between school roles and ICT implementation.

There was also a significant difference between educators and professional teachers. It was found that educators report a higher degree of ICT implementation. There were also differences between professional teachers who specialize in English and science. It was found that science teachers reported a higher degree of program implementation compared to English teachers. From this we learn that it is possible that ICT training is primarily focused on classroom educators. The assimilation of ICT is at an early stage, which is still not implemented by professional teachers, is also possible.

Moreover, the more positive the teachers' position on the change in the ICT program, the greater their degree of assimilation of the ICT program in their schools. There is also a moderately positive relationship between the emotional and cognitive domains versus the behavioural field. The teacher expresses and thinks that the change is necessary and correct, even if he does not show it in his behaviour. The more the teacher thinks that the change is correct, and feels that the change is worthwhile for the system, the better it will be assimilated. From this we can learn that teachers' willingness to change, pedagogic knowledge, and teacher confidence in the purpose of change is very important for the change to be effective (Donnelly, McGarr\& O'Reilly, 2011).

The findings of the study stress the need to emphasize the significance of pedagogy in implementing the change, although the change is in the field of ICT, the pedagogical aspect of the teacher's work is at the core of the process of assimilation and implementation of ICT (Ertmer\&Ottenbreit-Leftwich, 2010).

\section{References}

1. Abu Asba, H. 2007. Arab education in Israel: Dilemmas of a national minority. Jerusalem, the Floersheimer Institute for Policy Studies. (Hebrew)

2. Al-Harbi, H. 2014. Towards successful implementation of ICT in education. The 2014 WEI International Academic Conference Proceedings, April, 2014 Vienna, Austria. The West East institute, pp. 33-46.

3. Archambault, L., \& Crippen, K. 2009. Examining TPACK among K-12 online distance educators in the United States. Contemporary Issues in Technology and Teacher Education, 9(1), 71-88.

4. Avidov-Ungar, A., \&Arazi-Cohen, F. 2014. What Affects the Implementation of ICT in school? Technological Pedagogical Knowledge of the Teacher (TPACK), Attitudes towards change and implementing ICT. In, Y. Eshet- 
Alkalai A. Kaspi, N. Gari, Y. Kalman, \& V. Zilber-Varod (Eds.), the $9^{\text {th }}$ conference ofTPACK. Raanana, Israel, Open University, pp. 72-75. (Hebrew)

5. Avidov-Ungar, A.,\& Friedman, Y.2011. Empowering teachers - essence and examples. Information available for professionals. Jerusalem, The Henrietta Szold Institute.(Hebrew)

6. Avidov-Ungar, O. 2012. The Implications of teachers' professional attributes on assimilating a computerized learning and management system in an Israeli school: A case study. Creative Education, 3(08), 116-119.

7. Bingimlas, K.A. 2009. Barriers to the successful integration of ICT in teaching and learning environments: A review of the literature. Eurasia Journal of Mathematics, Science \& Technology Education, 5(3), 235-245.

8. Caspi, A., Gary, N., Kelman Y., \& Silber Varod, V., (Eds.) 2014. Proceedings of the $9^{\text {th }}$ Chase Conference on Researching Innovation and Learning Technology. Raanana, The Open University, pp. 10-17. (Hebrew)

9. Cuban, L. 2001. Leadership for student learning: Urban school leadership Different in kind and degree. Institute for Educational Leadership, Washington

de Freitas, S., \&Liarokapis, F. 2011. Serious games: a new paradigm for education? In M. Ma, A. Oikonomou, \& L.C. Jain (Eds.), Serious Games and Edutainment Applications (pp. 9-23). Springer, London.

10. De Freitas, S., \&Veletsianos, G. (2010). Crossing boundaries: Learning and teaching in virtual worlds. British Journal of Educational Technology, 41(1), 3-9.Rogers, E.M. 2003. Elements of diffusion. Diffusion of innovations $\left(5^{\text {th }}\right.$ $E d$.). New York: Free Press.

11. Donnelly, D., McGarr, O., \& O'Reilly, J. 2011. A framework for teachers' integration of ICT into their classroom practice. Computers \& Education, 57(2), 1469-1483.

12. Ertmer, P.A. 2005. Teacher pedagogical beliefs: The final frontier in our quest for technology integration. Educational technology research and development, 53(4), 25-39.

13. Ertmer, P.A., \&Ottenbreit-Leftwich, A.T. 2010. Teacher technology change: How knowledge, confidence, beliefs, and culture intersect. Journal of Research on Technology in Education, 423, 255-284.

14. Fullan, M. 2006. Leading professional learning. School Administrator, 6310, 10.

15. Ghamrawi, N. 2013. The relationship between the leadership styles of Lebanese public school principals and their attitudes towards ICT versus the level of ICT use by their teachers. Open Journal of Leadership, 201, 11-20.

16. Hills, J.E. 2009. Teachers' attitudes regarding inclusive education: Are our children being left behind? (Doctoral dissertation, Capella University).

17. Marsh, H.W. 2001. Distinguishing between good useful) and bad workloads on students' evaluations of teaching. American Educational Research Journal, 381, 183-212. 
18. Mioduser, T., Nachmias. R., Tobin, D., \&Forkosh, A., 2006. Pedagogic innovation combined with ICT and information technology. Tel Aviv, Ramot: Mofet Institute. (Hebrew)

19. Mishra, P. \& Koehler, M.J. 2008. Introducing technological pedagogical content knowledge. In the Annual Meeting of the American Educational Research Association (pp. 1-16). New York, March 24-28, 2008.

20. Palak, D., \& Walls, R.T. 2009. Teachers' beliefs and technology practices: A mixed-methods approach. Journal of Research on Technology in Education, 41(4), 417-441.

21. Rogers, E.M. 2003. Elements of diffusion. Diffusion of innovations $\left(5^{\text {th }}\right.$ Ed. $)$. New York: Free Press.

22. Selwyn, N. 2010. Looking beyond learning: Notes towards the critical study of educational technology. Journal of Computer Assisted Learning, 26(1), 6573.

23. Shulman, L.S. 1986. Those who understand: Knowledge growth in teaching. Educational Researcher, 15(2), 4-14.

24. Venezky, R.L., \& Davis, C. 2002. Quo vademus? The transformation of schooling in a networked world. Version 8c. OECD Centre for Educational Research and Innovation, Paris. (www. oecd. org/pdf/M00027000/ M00027107. pdf). 